\title{
Erratum to: Negative and positive life experiences in patients with psoriatic arthritis
}

Edita Simonić $\cdot$ Sandra Peternel $\cdot$ Liliana Stojnić-Soša •

Ika Rončević-Gržeta $\cdot$ Larisa Prpić-Massari · Dražen Massari •

Darinka Periša $\cdot$ Leo Čabrijan • Marija Kaštelan

Published online: 29 January 2013

(c) Springer-Verlag Berlin Heidelberg 2013

\section{Erratum to: Rheumatol Int}

DOI 10.1007/s00296-012-2569-z

The corresponding author of the manuscript was inadvertently omitted the author name Marija Kaštelan from the author group of the published article. The revised author group is given below.

Edita Simonić · Sandra Peternel · Liliana Stojnić-Soša ·

Ika Rončević-Gržeta · Larisa Prpić-Massari ·

Dražen Massari · Darinka Periša · Leo Čabrijan ·

Marija Kaštelan

The online version of the original article can be found under doi:10.1007/s00296-012-2569-z.

E. Simonić $(\bowtie) \cdot$ S. Peternel · L. Stojnić-Soša ·

L. Prpić-Massari · D. Periša · L. Čabrijan · M. Kaštelan

Department of Dermatovenerology, Clinical Hospital

Center Rijeka, University of Rijeka, Krešimirova 42,

51000 Rijeka, Croatia

e-mail: sedita@medri.hr

I. Rončević-Gržeta

Department of Psychiatry, Clinical Hospital Center Rijeka,

University of Rijeka, Rijeka, Croatia

D. Massari

Department of Rheumatology, Medical Faculty of Rijeka, Thalassotherapija Opatija, Special Hospital for Rehabilitation

of Heart and Lung Diseases and Rheumatism, Opatija, Croatia 